\title{
Regeneration of Sugarcane genotypes Under Different Level of Sodium Chloride Salt
}

\section{Kuasha Mahmud ${ }^{1}$, Nadira Islam², Asish Kumar Ghose ${ }^{2}$, Md Abdul Azim ${ }^{1 *}$, Md Rashedur Rahman Rajib ${ }^{2}$ and Md Jahirul Islam ${ }^{2}$}

${ }^{1}$ Biotechnology Division, Bangladesh Sugarcrop Research Institute, Pabna, Bangladesh

${ }^{2}$ Physiology and Sugar Chemistry Division, Bangladesh Sugarcrop Research Institute, Pabna, Bangladesh

*Corresponding Author: Md Abdul Azim, Scientific Officer, Biotechnology Division, Bangladesh Sugarcrop Research Institute, Ishurdi, Pabna, Bangladesh.
Received: January 12, 2021

Published: February 27, 2021

(C) All rights are reserved by Kuasha

Mahmud., et al.

\begin{abstract}
The effects of Murashige and Skoog medium supplemented with different Sodium Chloride salt $(\mathrm{NaCl})$ concentrations $(0,50,100$, 150, 200, 250 and $300 \mathrm{mM}$ ) containing 2, 4-D (3 mg/l) along with green coconut water (10\%) on explants (leaf sheath) of four sugarcane genotypes were aimed for their callus formation ability and production of embryogenic callus. Besides, regeneration potentiality of sugarcane genotypes including shooting and rooting ability under different levels of NaCl concentrations $(0,50,100,150,200$, 250 and $300 \mathrm{mM}$ ) was evaluated. MS medium supplemented with $50 \mathrm{mM} \mathrm{NaCl}$ produced the highest callus (83.33\%) in Isd 16 variety followed by BSRI Akh 41 (83\%) and Mutant CC $37 \mathrm{M}_{5}$ produced the lowest (66.66\%)). But no callus was produced supplemented with $300 \mathrm{mM} \mathrm{NaCl}$ in all genotype. The highest shoot and root regeneration (91\% and 92\%) were obtained from MS medium fortified with $50 \mathrm{mM} \mathrm{NaCl}$ containing shooting media combination BAP (6-Benzylaminopurine) $2 \mathrm{mg} / \mathrm{l}+\mathrm{KN}$ (Kinetin) $1 \mathrm{mg} / \mathrm{l}$ and rooting media NAA (1-Naphthaleneacetic acid) $5 \mathrm{mg} / \mathrm{l}$ respectively in BSRI Akh 41. On the other hand, little or no shoot and root were initiated from Isd 16, CC37 $\mathrm{M}_{5}$ and BSRI Akh 42 under above mentioned shooting and rooting media. Callus, shoot and root as well as regeneration ability of plant is highly correlated with callus, shoot and root formation. Significant differences were observed for callus, shoot and root regeneration capacity among all the four genotypes. It revealed that callus, shoot and root regeneration performance ability was decreased by increasing of $\mathrm{NaCl}$ concentration levels.
\end{abstract}

Keywords: Sugarcane; Callus; 2, 4-D; NaCl; Regeneration and Salt Tolerant

\section{Abbreviations}

mM: Milli Mole; 2, 4-D= 2,4-Dichlorophenoxyacetic Acid; BSRI: Bangladesh Sugarcrop Research Institute; CC: Clone; MS Medium: Murashige and Skoog Medium; BAP: 6-Benzylaminopurine; KN: Kinetin; NAA: 1-Naphthaleneacetic Acid; NaOH: Sodium Hydroxide; $\mathrm{kg} \mathrm{cm}^{-2}$ : Kilogram Per Centimeter Square; ANOVA: Analysis of Variance

\section{Introduction}

Sugarcane (Saccharum officinarum L.) is considered as an important agro-industrial, semi-perennial sugar producing monocot crop which cultivation occurs in the more than 80 tropical and subtropical regions [1-3]. About 70\% of the world's sugar production is contributed by this complex polyploidy crop. Globally, about $2.6 \mathrm{M}$ ha of land are being occupied, a little about $2 \%$ of the total cropped area, producing 1907 million MT of cane [4]. Nearly 60 countries 
over the world's are being cultivated sugarcane as a valuable commercial crop for producing sugar and bioethanol [5]. Unfortunately, several diseases and abiotic stresses such as salinity, drought and freezing are responsible for decreasing the production of this crop [6]. However, being a typical glycophyte, it exhibits stunted growth or no growth, chlorophyll contents and represents the toxic damages, i.e. wilting, chlorosis, necrosis with its yield falling up to $50 \%$ especially sugar content when cultivated in the salt-affected soils [7-9]. Salt-affected soil is enriched with a variety of salts, which are quickly dissolved in water to produce toxic ions, especially sodium ion [10]. The improvement of sugarcane plant resistance to salt stress is of great importance for Bangladesh. Callus culture is a supplementary tool to traditional breeding for the production of stress-resistant plants in sugarcane using a multitude of biochemical, physiological and morphological indices [8,9,11-14]. In vitro selection program of a given genotype depends on its aptitude to in vitro culture, essentially to induction of embryogenic callus and regeneration of plantlets. A variation observed among the four genotypes which regenerated from tissues termed somaclonal variation [15] has been considered as a source of new plant genotype for further crop improvement. In vitro mutagenesis can be beneficial for the development of Somaclonal variation to the isolation of salinity tolerant lines in a short duration [16-18]. However, several variants are often uncertain or non-heritable being epigenetic changes rather than genetic changes. Such epigenetic alterations may result in false-positive signals if one seeks mutational change in a particular phenotype $[19,20]$.

The productivity of sugarcane is worldwide subjected to increasing environmental constraints, predominantly to drought and salinity. salinity is a serious limitation for the production of sugarcane in southern region of Bangladesh [21]. Sugarcane is moderate sensitivity to salinity stress and confined to tropical and sub-tropical irrigated regions, where salinity is an ever-increasing problem. Germination, growth rate, cane yield as well as sucrose content in cane are highly affected by the soil containing high level of salts [22]. Salinity is one of the most serious menaces to crop production. Sugarcane has been categorized as a glycophytic (salt susceptible); because it exhibits toxic symptoms including limited sprout emergence, nutritional imbalance and growth reduction, leading to low productivity, especially sugar content when cultivated in the salt-affected soils [10]. The severe sensitivity of sugarcane to salinity at various growth stages is manifested by a considerable reduction in growth rate [12].

\section{Aim of the Study}

We aimed to observe the in vitro response to identify the salt tolerant and susceptible genotypes through in vitro micropropagation based on in vitro phenotypic performance. Therefore, the experiment was conducted to find out salt tolerant callusing, shooting and rooting performance ability as well as developing salt tolerant variety for the southern region in Bangladesh.

\section{Materials and Methods}

\section{Plant material}

Four sugarcane genotypes (Isd 16, CC37M $\mathrm{M}_{5}$, BSRI Akh 41 and BSRI Akh 42) were evaluated for their response to callus induction capacity, shooting and rooting performance under control, $50 \mathrm{mM}$ $\mathrm{NaCl}, 100 \mathrm{mM} \mathrm{NaCl}, 150 \mathrm{mM} \mathrm{NaCl}, 200 \mathrm{mM} \mathrm{NaCl}, 250 \mathrm{mM} \mathrm{NaCl}$, $300 \mathrm{mM} \mathrm{NaCl}$ were arranged in completely randomized design (CRD) with five replications.

\section{Callus induction}

The explants used for callus induction are leaf cylinders provided from the sheath of the four youngest genotypes. The basal part of the stem (constituted by the sheath of leaves) was surface sterilized for 10 mins in $0.03 \%$ mercuric chloride supplemented with Tween 80 followed by three rinses with sterile distilled water (10 min each). After drying on sterile filter paper, leaf cylinders were aseptically placed on based MS medium [23] supplemented with $4 \mathrm{mg} / \mathrm{L} \mathrm{2,4-D} \mathrm{and} 30 \mathrm{~g} / \mathrm{L}$ sucrose using different levels of Sodium Chloride salt ( 0 mM, 50 mM, 100 mM, 150 mM, 200 mM, $250 \mathrm{mM}$ and $300 \mathrm{mM}$ ). The $\mathrm{pH}$ was adjusted to 5.8 with $0.1 \mathrm{~N} \mathrm{NaOH}$ before autoclaving at $121^{\circ} \mathrm{C}$ and $1.2 \mathrm{~kg} \mathrm{~cm}^{-2}$ for 30 minutes and all media were solidified with $6.5 \mathrm{gm} / \mathrm{L}$ agar before autoclaving during 20 mins at $120^{\circ} \mathrm{C}$. Each ex-plant per 36 test tubes was cultivated and cultures were kept in dark at $25 \pm 1^{\circ} \mathrm{C}$. Callus induction percentage was determined after 4 weeks [24]. For the salt shock treatment, the callus was transferred on medium to culture medium with the concentrations with different saline condition.

\section{Shooting initiation}

After two subcultures ( 4 weeks each), callus were transferred in test tubes containing the shooting medium (BAP $2 \mathrm{mg} / \mathrm{L}$ and Kinetin $1 \mathrm{mg} / \mathrm{L}$ ) of regeneration (MS modified) with $30 \mathrm{~g} / \mathrm{L}$ of sucrose using different levels of $\mathrm{NaCl}$ salt. Cultures were incubated in growth cabinet at $25 \pm 1^{\circ} \mathrm{C}$ under 16 -h photoperiod Callus that regenerate plant shoots were recorded after 5 weeks [22] and the 
data were expressed as a percentage of regenerated callus and total number of callus transferred for regeneration.

\section{Rooting initiation}

After shooting initiation, plantlets were transferred in test tubes containing the rooting medium (NAA $5 \mathrm{mg} / \mathrm{L}$ ) of regeneration (MS modified) with $30 \mathrm{gm} / \mathrm{L}$ of sucrose using different levels of $\mathrm{NaCl}$ salt. Cultures were incubated in a growth cabinet at $25 \pm 1^{\circ} \mathrm{C}$ under 16-h photoperiod for rooting that regenerate roots were recorded after 3 to 4 weeks [24].

\section{Acclimatization of regenerated plants}

The regenerated plantlets were aseptically transferred to the same rooting medium after 4 weeks. Plantlets with at least five well-developed roots were transferred to a pot containing soil with coco dust under high humidity ( $>90 \%$ ) by covering the plants with plastic envelops after cutting their leaves [25]. For acclimatization, pots were placed in hardening shed.

\section{Statistical analysis}

All the data were statistically analyzed by Statistix 10 (Tallahassee, FL 32312, USA) as ANOVA with Multiple comparison of number of explants that induced callus percentage, callus weight, shooting initiation percentage, shoot number per plant, shoot height per plant, rooting initiation percentage, root number per plant, root height per plant.

\section{Results}

\section{Callus induction performance}

Callus induction rate varied from 0 to $100 \%$ under all the treatments. High callus induction percentages revealed the high capacity of the sugarcane genotypes grow under saline conditions. In control, all the genotypes produced $100 \%$ callus induction. But when applied $50 \mathrm{mM} \mathrm{NaCl}$ almost forty to fifty percent callus induction reduced among the genotypes. The highest callus induction percentage was found in Isd 16 under all treatments. The lowest callus induction percentage was found in CC $37 \mathrm{M}_{5}$ under all $\mathrm{NaCl}$ concentrations. However, among the saline treatments, highest callus observed in $50 \mathrm{mM} \mathrm{NaCl}$ and the lowest found in 200 $\mathrm{mM} \mathrm{NaCl}$ concentration. Callus induction performance drastically reduced from above $150 \mathrm{mM} \mathrm{NaCl}$ concentration. In contrary from the four genotypes and BSRI Akh 41 performed better callus induction in different saline conditions. These results indicated that the ability of callus induction greatly influenced by the genotype in different saline conditions.

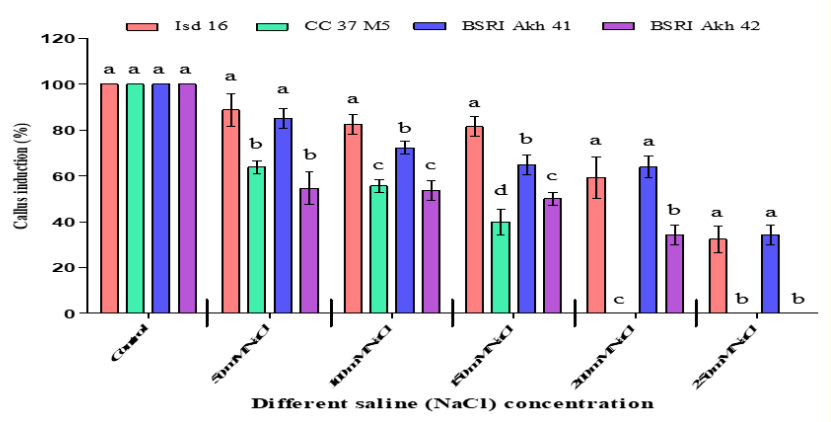

Figure 1: Effects of salt $(\mathrm{NaCl})$ on callus induction percentage (\%) among four sugarcane genotypes.

\section{Callus weight performance}

Callus weight rates were varied from 0 to 2.94 gm (Table 1 ) under all treatments. A significant difference $(p<0.01)$ was observed among genotypes which is supported the result of Gandonou., et al. 2005 [18].

\begin{tabular}{|l|c|c|c|c|c|c|}
\hline Genotype & Control & $\begin{array}{c}\mathbf{5 0} \\
\mathbf{m M} \\
\mathbf{N a C l}\end{array}$ & $\begin{array}{c}\mathbf{1 0 0} \\
\mathbf{m M} \\
\mathbf{N a C l}\end{array}$ & $\begin{array}{c}\mathbf{1 5 0} \\
\mathbf{m M} \\
\mathbf{N a C l}\end{array}$ & $\begin{array}{c}\mathbf{2 0 0} \\
\mathbf{m M} \\
\mathbf{N a C l}\end{array}$ & $\begin{array}{c}\mathbf{2 5 0} \\
\mathbf{m M} \\
\mathbf{N a C l}\end{array}$ \\
\hline Isd 16 & $2.01 \mathrm{~b}$ & $1.36 \mathrm{a}$ & $0.84 \mathrm{~b}$ & $1.20 \mathrm{a}$ & $0.16 \mathrm{a}$ & $0.01 \mathrm{a}$ \\
\hline CC $37 \mathrm{M}_{5}$ & $1.92 \mathrm{~b}$ & $0.58 \mathrm{~b}$ & $0.24 \mathrm{~d}$ & $0.00 \mathrm{c}$ & $0.00 \mathrm{~b}$ & $0.00 \mathrm{a}$ \\
\hline $\begin{array}{l}\text { BSRI Akh } \\
41\end{array}$ & $2.94 \mathrm{a}$ & $1.37 \mathrm{a}$ & $1.20 \mathrm{a}$ & $0.11 \mathrm{~b}$ & $0.02 \mathrm{~b}$ & $0.00 \mathrm{a}$ \\
\hline $\begin{array}{l}\text { BSRI Akh } \\
42\end{array}$ & $1.92 \mathrm{~b}$ & $1.38 \mathrm{a}$ & $0.47 \mathrm{c}$ & $0.19 \mathrm{~b}$ & $0.00 \mathrm{~b}$ & $0.00 \mathrm{a}$ \\
\hline $\begin{array}{l}\text { Level of } \\
\text { Signifi- } \\
\text { cance }\end{array}$ & $* *$ & $* *$ & $* *$ & $* *$ & $* *$ & $* *$ \\
\hline CV (\%) & 7.49 & 23.79 & 23.79 & 20.98 & 59.19 & 47.21 \\
\hline
\end{tabular}

Table 1: Performance of callus weight of four sugarcane genotypes under different saline conditions.

CV: Co-Efficient of Variation; mM: Millimole; NaCl: Sodium Chloride; $\mathrm{CC}$ : Somaclone. 
The results indicated that callus weights were varied significantly under saline conditions. The highest callus weight was found in Isd 16 (2.01g 1.36g, 1.20g, 0.16g) under control, $50 \mathrm{mM} \mathrm{NaCl}$, $150 \mathrm{mM} \mathrm{NaCl}, 200 \mathrm{mM} \mathrm{NaCl}$ conditions respectively. The lowest callus weight was observed in CC $37 \mathrm{M}_{5}(1.92,0.58,0.24,0.00 \mathrm{~g})$ under control condition with four treatments including $50 \mathrm{mM} \mathrm{NaCl}$, $100 \mathrm{mM} \mathrm{NaCl}, 150 \mathrm{mM} \mathrm{NaCl}, 200 \mathrm{mM} \mathrm{NaCl}$.

\section{Shooting initiation performance}

Shooting initiation varied from 0 to $100 \%$ under all treatments (Figure 2). High shooting initiation percentages revealed the maximum number of the sugarcane genotypes. In the control condition, all genotypes produced $100 \%$ shooting initiation except BSRI Akh $42(83.33 \%)$.

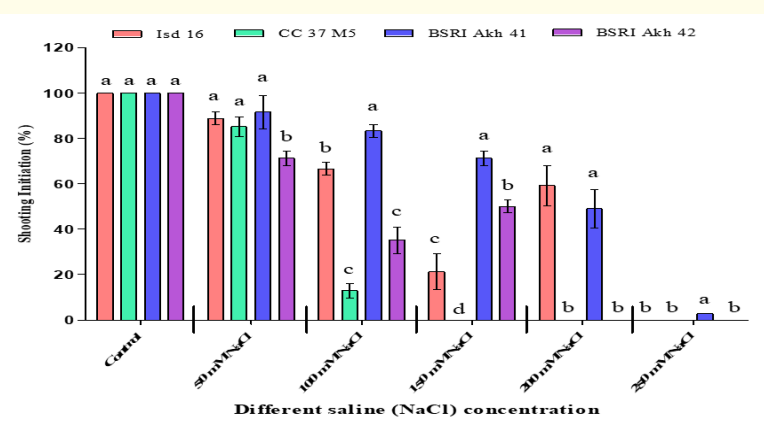

Figure 2: Effects of salt $(\mathrm{NaCl})$ on shooting initiation percentage (\%).

But when applied $\mathrm{NaCl}$ almost shooting initiation were reduced. From the four genotypes highest shooting initiation was Isd 16 $(100.00 \%, 88.80 \%, 66.60 \%, 21.20 \%, 7.20 \%)$ and the lowest was $\mathrm{CC} 7 \mathrm{M}_{5}(100.00 \%, 85.80 \%, 13.10 \%, 0)$. These results indicated that the highest rate of shoot differentiation was greatly influenced by the genotype and different saline conditions.

\section{Shoot height performance}

Shoot height varied from 0 to $37.99 \mathrm{~cm}$ under different treatments. The effects of genotypes on shoot height are shown in table 2 . The results indicated that shoots height varied significantly under saline condition.

\begin{tabular}{|l|c|c|c|c|c|c|}
\hline Genotype & Control & $\begin{array}{c}\mathbf{5 0} \mathbf{~ m M} \\
\mathbf{N a C l}\end{array}$ & $\begin{array}{c}\mathbf{1 0 0} \mathbf{~ m M} \\
\mathbf{N a C l}\end{array}$ & $\begin{array}{c}\mathbf{1 5 0} \mathbf{~ m M} \\
\mathbf{N a C l}\end{array}$ & $\begin{array}{c}\mathbf{2 0 0} \\
\mathbf{m M} \\
\mathbf{N a C l}\end{array}$ & $\begin{array}{c}\mathbf{2 5 0} \\
\mathbf{m M} \\
\mathbf{~ N a C l}\end{array}$ \\
\hline Isd 16 & $22.52 \mathrm{~b}$ & $19.14 \mathrm{a}$ & $14.58 \mathrm{a}$ & $12.46 \mathrm{a}$ & $1.46 \mathrm{a}$ & $0.02 \mathrm{a}$ \\
\hline CC37M $_{5}$ & $23.10 \mathrm{~b}$ & $17.06 \mathrm{ab}$ & $2.68 \mathrm{c}$ & $0.00 \mathrm{c}$ & $0.00 \mathrm{~b}$ & $0.00 \mathrm{a}$ \\
\hline $\begin{array}{l}\text { BSRI Akh } \\
41\end{array}$ & $37.99 \mathrm{a}$ & $20.00 \mathrm{a}$ & $16.58 \mathrm{a}$ & $11.68 \mathrm{a}$ & $0.32 \mathrm{~b}$ & $0.00 \mathrm{a}$ \\
\hline $\begin{array}{l}\text { BSRI Akh } \\
42\end{array}$ & $22.80 \mathrm{~b}$ & $13.96 \mathrm{~b}$ & $10.56 \mathrm{~b}$ & $1.94 \mathrm{~b}$ & $0.00 \mathrm{~b}$ & $0.00 \mathrm{a}$ \\
\hline $\begin{array}{l}\text { Level of } \\
\text { Signifi- } \\
\text { cance }\end{array}$ & $* *$ & $* *$ & $* *$ & $* *$ & $* *$ & $* *$ \\
\hline CV $(\%)$ & 10.45 & 14.50 & 24.76 & 13.18 & 37.03 & 44.21 \\
\hline
\end{tabular}

Table 2: Performance of shoot height $(\mathrm{cm})$ of four sugarcane genotypes under different saline conditions.

CV: Co-Efficient of Variation; mM: Millimole; NaCl: Sodium Chloride; CC: Somaclone.

From the four genotypes, the highest shoot height was found in BSRI Akh 41 but the tolerance level highest in Isd 16 than BSRI Akh 41 and the lowest was CC $37 \mathrm{M}_{5}(17.06 \mathrm{~cm}, 2.68 \mathrm{~cm}, 0 \mathrm{~cm})$. Significant difference $(\mathrm{p}<0.01)$ was observed among genotypes (Table 2).

Shoot number per plant performance

Shoot number varied from 0 to 16.58 under all treatments. The results indicated that shoot numbers were varied significantly under saline conditions.

\begin{tabular}{|c|c|c|c|c|c|c|}
\hline Genotype & Control & $\begin{array}{c}50 \mathrm{mM} \\
\mathrm{NaCl}\end{array}$ & $\begin{array}{c}100 \mathrm{mM} \\
\mathrm{NaCl}\end{array}$ & $\begin{array}{c}150 \\
\mathrm{mM} \\
\mathrm{NaCl}\end{array}$ & $\begin{array}{c}200 \\
\mathrm{mM} \\
\mathrm{NaCl}\end{array}$ & $\begin{array}{c}250 \\
\mathrm{mM} \\
\mathrm{NaCl}\end{array}$ \\
\hline Isd 16 & $10.40 \mathrm{~b}$ & $9.00 \mathrm{~b}$ & $14.58 \mathrm{a}$ & $3.80 \mathrm{~b}$ & $2.60 \mathrm{a}$ & $0.40 \mathrm{a}$ \\
\hline $\mathrm{CC} 7 \mathrm{M}_{5}$ & $6.40 c$ & $6.80 \mathrm{~b}$ & $2.68 \mathrm{c}$ & $0.00 \mathrm{~d}$ & $0.00 \mathrm{~b}$ & $0.00 \mathrm{a}$ \\
\hline BSRI Akh 41 & $10.00 \mathrm{~b}$ & $9.20 \mathrm{~b}$ & $16.58 \mathrm{a}$ & $4.60 \mathrm{a}$ & $2.20 \mathrm{a}$ & $0.00 \mathrm{a}$ \\
\hline BSRI Akh 42 & $15.40 \mathrm{a}$ & $15.40 \mathrm{a}$ & $10.56 \mathrm{~b}$ & $2.60 c$ & $0.00 \mathrm{~b}$ & $0.00 \mathrm{a}$ \\
\hline $\begin{array}{l}\text { Level of } \\
\text { Significance }\end{array}$ & $* *$ & $* *$ & $* *$ & $* *$ & $* *$ & NS \\
\hline CV (\%) & 22.43 & 24.85 & 19.71 & 20.73 & 51.03 & 47.21 \\
\hline
\end{tabular}

Table 3: Performance of shoot number per plant of four sugarcane genotypes under different saline conditions. CV: Co-Efficient of Variation; mM: Millimole; NaCl: Sodium Chloride; CC: Somaclone. 
Isd 16 produced significant shoot number up to $200 \mathrm{mM} \mathrm{NaCl}$ and $\mathrm{CCR}_{5} 37 \mathrm{M}_{5}$ produced shoot number up to $100 \mathrm{mM} \mathrm{NaCl}$.

Rooting initiation performance under different saline conditions

From four sugarcane genotypes up to $88.88 \%$ rooting initiation percentage observed (Figure 3).

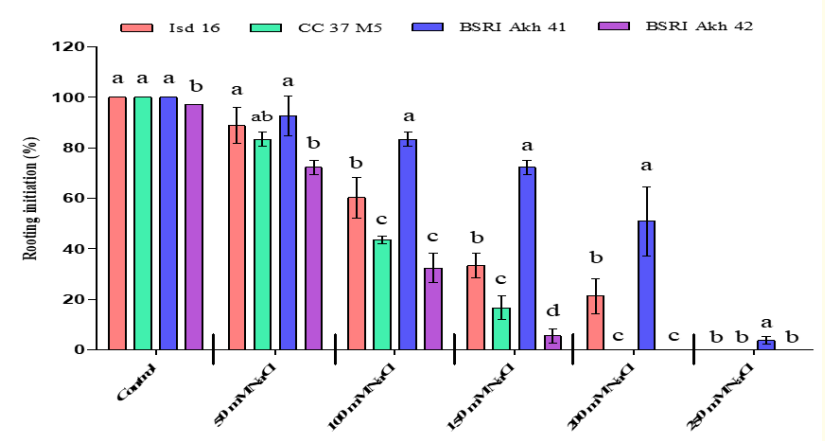

Figure 3: Effects of salt $(\mathrm{NaCl})$ on rooting initiation percentage (\%).

The highest rooting initiation was found in BSRI Akh 41 (92\%, $83.33 \%, 72.22 \%, 50 \%, 2.77 \%)$ and lowest was CC $37 \mathrm{M}_{5}(72.22 \%$, $30.55 \%, 5.5 \%)$. These results indicated that rooting initiation differentiation was vary from genotype to genotype in different saline conditions.

\section{Root height}

The results indicate that root height varied significantly with the varieties and it ranged from 0 to 4.46 . In $100 \mathrm{mM} \mathrm{NaCl}$ the highest root height found in Isd $16(3.16 \mathrm{~cm}, 3.84 \mathrm{~cm}, 4.46 \mathrm{~cm})$ and the lowest found in CC37M5 $(2.02 \mathrm{~cm}, 1.78 \mathrm{~cm}, 0.14 \mathrm{~cm})$. From 150 $\mathrm{mM} \mathrm{NaCl}$ to $200 \mathrm{mM} \mathrm{NaCl}$, the highest root height found BSRI Akh $41(0.74 \mathrm{~cm}, 0.14 \mathrm{~cm})$ and the lowest found in $\mathrm{CC}_{3} \mathrm{M}_{5}(0 \mathrm{~cm}, 0$ $\mathrm{cm})$. BSRI Akh 41 performed better root height than other three genotypes.

\section{Root number per plant}

The results indicate that root numbers were varied significantly with the varieties and it ranged from 0 to 16.00 . Upto $100 \mathrm{mM} \mathrm{NaCl}$

\begin{tabular}{|l|c|c|c|c|c|c|}
\hline Genotype & Control & $\begin{array}{c}\mathbf{5 0} \mathbf{~ m M} \\
\mathbf{N a C l}\end{array}$ & $\begin{array}{c}\mathbf{1 0 0} \mathbf{~ m M} \\
\mathbf{N a C l}\end{array}$ & $\begin{array}{c}\mathbf{1 5 0} \mathbf{~ m M} \\
\mathbf{N a C l}\end{array}$ & $\begin{array}{c}\mathbf{2 0 0} \\
\mathbf{m M} \\
\mathbf{N a C l}\end{array}$ & $\begin{array}{c}\mathbf{2 5 0} \\
\mathbf{m M} \\
\mathbf{N a C l}\end{array}$ \\
\hline Isd 16 & $3.16 \mathrm{a}$ & $3.84 \mathrm{a}$ & $4.46 \mathrm{a}$ & $0.40 \mathrm{~b}$ & $0.06 \mathrm{~b}$ & 0.00 \\
\hline CC37M $_{5}$ & $2.02 \mathrm{c}$ & $1.78 \mathrm{c}$ & $0.14 \mathrm{c}$ & $0.00 \mathrm{c}$ & $0.00 \mathrm{c}$ & 0.00 \\
\hline $\begin{array}{l}\text { BSRI Akh } \\
41\end{array}$ & $3.02 \mathrm{ab}$ & $2.76 \mathrm{~b}$ & $1.16 \mathrm{~b}$ & $0.74 \mathrm{a}$ & $0.14 \mathrm{~b}$ & 0.00 \\
\hline $\begin{array}{l}\text { BSRI Akh } \\
42\end{array}$ & $2.34 \mathrm{bc}$ & $1.14 \mathrm{c}$ & $0.30 \mathrm{c}$ & $0.16 \mathrm{c}$ & $0.00 \mathrm{c}$ & 0.00 \\
\hline $\begin{array}{l}\text { Level of } \\
\text { Signifi- } \\
\text { cance }\end{array}$ & $* *$ & $* *$ & $* *$ & $* *$ & $* *$ & $\mathrm{M}$ \\
\hline CV $(\%)$ & 20.59 & 21.59 & 18.79 & 52.40 & 77.46 & $\mathrm{M}$ \\
\hline
\end{tabular}

Table 4: Performance of root height $(\mathrm{cm})$ of four sugarcane genotypes under different saline conditions.

CV: Co-Efficient of Variation; mM: Millimole; NaCl: Sodium Chloride; CC: Somaclone.

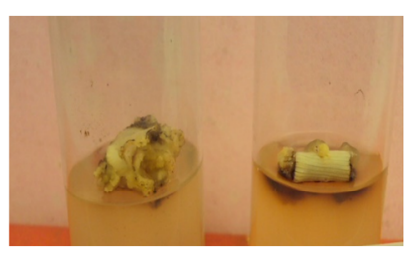

(A)

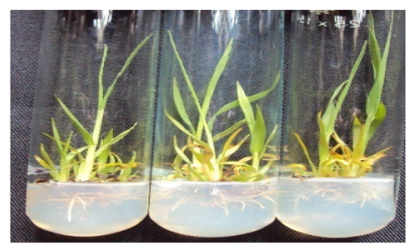

(C)

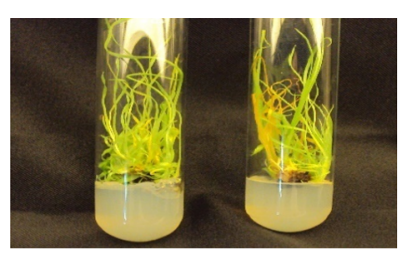

(B)

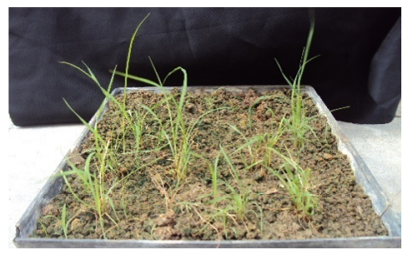

(D)
Figure 4: Callus induction performance (A), Shoot initiation performance (B), Root initiation performance (C), Plantlets (D) of Isd 16 in vitro saline conditions (150 mM NaCl).

the highest root number per plant found in Isd 16 (15.80, 14.6, 6.60) which is statistically similar to BSRI Akh 41 and the lowest found in $\mathrm{CC}_{3} \mathrm{M}_{5}(10,11.60,1.80)$. 


\begin{tabular}{|l|c|c|c|c|c|c|}
\hline Genotype & Control & $\begin{array}{c}\mathbf{5 0} \mathbf{~ m M} \\
\mathbf{N a C l}\end{array}$ & $\begin{array}{c}\mathbf{1 0 0} \mathbf{~ m M} \\
\mathbf{N a C l}\end{array}$ & $\begin{array}{c}\mathbf{1 5 0} \\
\mathbf{m M} \\
\mathbf{N a C l}\end{array}$ & $\begin{array}{c}\mathbf{2 0 0} \\
\mathbf{m M} \\
\mathbf{N a C l}\end{array}$ & $\begin{array}{c}\mathbf{2 5 0} \\
\mathbf{m M} \\
\mathbf{N a C l}\end{array}$ \\
\hline Isd 16 & $15.80 \mathrm{a}$ & $14.60 \mathrm{a}$ & $6.60 \mathrm{a}$ & $2.40 \mathrm{~b}$ & $1.20 \mathrm{a}$ & 0.00 \\
\hline CC 37 M & $10.00 \mathrm{~b}$ & $11.60 \mathrm{a}$ & $1.80 \mathrm{~b}$ & $0.00 \mathrm{c}$ & $0.00 \mathrm{~b}$ & 0.00 \\
\hline BSRI Akh 41 & $12.00 \mathrm{~b}$ & $13.00 \mathrm{a}$ & $5.00 \mathrm{a}$ & $3.40 \mathrm{a}$ & $1.80 \mathrm{a}$ & 0.00 \\
\hline BSRI Akh 42 & $16.60 \mathrm{a}$ & $5.60 \mathrm{~b}$ & $2.60 \mathrm{~b}$ & $2.00 \mathrm{~b}$ & $0.00 \mathrm{~b}$ & 0.00 \\
\hline $\begin{array}{l}\text { Level of } \\
\text { Significance }\end{array}$ & $* *$ & $* *$ & $* *$ & $* *$ & $* *$ & $\mathrm{M}$ \\
\hline CV (\%) & 12.47 & 24.00 & 38.12 & 19.86 & 18.88 & $\mathrm{M}$ \\
\hline
\end{tabular}

Table 5: Performance of root number per plant of four sugarcane genotypes under different saline conditions.

CV: Co-Efficient of Variation; mM: Millimole; NaCl: Sodium

Chloride; CC: Somaclone.

From $150 \mathrm{mM} \mathrm{NaCl}$ to $200 \mathrm{mM} \mathrm{NaCl}$, the highest root number found BSRI Akh $41(2.40,1.20)$ and the lowest found in CC $37 \mathrm{M}_{5}(0$, $0)$. So BSRI Akh 41 performed a better number of roots than other three genotypes.

\section{Discussion}

Callus induction parameters

These results are in agreement with an earlier report in sugarcane where a significant decline in callus growth rate occurred with $150 \mathrm{mM} \mathrm{NaCl}[14,26]$. Nutritional imbalance is the main factor for declining callus growth upon $(\mathrm{NaCl})$ salt stress due to an interference of salt ions, such as $\mathrm{Na}^{+}$and $\mathrm{Cl}^{-}$with essential nutrients involved in both uptake and translocation processes [25]. The decreased cell viability in salt-stressed calli may be associated with toxic effects of increased $\mathrm{Na}^{+}$and reduced $\mathrm{K}^{+}$contents. A reduction in cell viability was also reported in tobacco in response to salt stress [27]. Salt stress compromised membrane integrity in all the genotypes for callus induction. Furthermore, membrane damage as well as tissue injury caused by $\mathrm{NaCl}$ application to fail callus formation [28].

\section{Shotting initiation parameters}

In addition, shooting initiation was slower and the yellowish of older leaves arises due to the osmotic effect of salt stress because Organic solutes (sugars, proline, polyols, quaternary ammonium compounds like glycine betaine, and other low molecular weight metabolites) serve a function in cells to lower or balance the osmotic potential of intracellular and extracellular ions to tolerate osmotic stresses [24]. Inorganic ions mainly $\mathrm{Na}^{+}, \mathrm{K}^{+}, \mathrm{Ca}^{2+}$ and $\mathrm{Cl}^{-}$also make great contribution in osmotic adjustment [29]. But the toxicity of $\mathrm{Na}^{+}, \mathrm{K}^{+}, \mathrm{Ca}^{2+}$ decreased the plant growth. The leaves of plants showed succulence under salt stress condition mainly attributed to increased vacuole size in leaves that accumulate salt $[24,30]$.

Shoot heights were drastically decreased due to increase of $\mathrm{NaCl}$ concentrations. Salinity imposes diffusive and metabolic limitations to photosynthesis, affects cell growth by restricting water uptake and cell turgor, resulting in increasing accumulation of $\mathrm{Na}^{+}$ and $\mathrm{Cl}^{-}$ions inside the cell. As a result, shoot height become stunted [4].

\section{Rooting initiation parameters}

The saline stress leads to the increase of $\mathrm{Na}^{+}$with the consequent decrease of $\mathrm{K}^{+}$in the plant, both on the leaves and in the roots [31]. $\mathrm{K}^{+}$is the most abundant inorganic cation in plant cells, which composed with nitrogen $(\mathrm{N})$ and phosphorus $(\mathrm{P})$ is fundamental for crop yield [32]. When $\mathrm{NaCl}$ was gradually added to the culture medium, the cation concentration in the tissue of the salttreated plants was lower than that of the non-stressed plants and inhibits root development [33].

Restriction of shoot and root development is the basic response to the stress (Bars., et al. 1962). Inhibition of root growth by salinity decrease the uptake of water and essential minerals, diminished supply of water and nutrients to shoot, which might contribute to growth reduction (Bars., et al. 1962).

\section{Conclusion}

Our findings showed that Sugarcane genotypes were significantly different in their capacity of the callus induction, production of the embryogenic callus and regeneration of plantlets when grown in the presence of NaCI. The genotypes Isd 16 had the lowest performance in root system under different saline conditions but revealed the highest performance in case of callus initiation percentage, callus weight, shooting initiation percentage and shooting height under salinity stress. So Isd 16 genotype appeared to possess the highest potential of making better growth among four sugarcane genotypes. On the other hand, genotypes CC 37 $M_{5}$ had the lowest performance in all parameters under different salt stress. CC $37 \mathrm{M}_{5}$ genotype appeared to possess salt susceptible 
among four sugarcane genotypes. Wide differences in the growth of sugarcane genotypes observed in this experiment encourage screening of more genotypes against salinity, especially in the field, to identify salt tolerant genotypes in Bangladesh.

\section{Acknowledgements}

Authors are grateful to Ministry of Agriculture of Bangladesh for providing financial support for the project "Development of Salt Tolerant Sugarcane Somaclones and Their Field Evaluation in Southern Region in Bangladesh" under special budget of Ministry of Agriculture and Bangladesh Sugarcrop Research Institute (BSRI) and also Bangladesh Agricultural Research Council (BARC) authority for their cooperation.

\section{Conflict of Interest}

There is no competing interest among the authors of this research.

\section{Bibliography}

1. Borba Maria Madalena Zocoller and Alex Marques Bazzo. "Estudo econômico do ciclo produtivo da cana-de-açúcar para reforma de canavial, em área de fornecedor do Estado de São Paulo". Congresso Da Sociedade Brasileira De Economia, Administração E Sociologia Rural 47 (2009).

2. Cordeiro Giovanni., et al. "Sugarcane". Pulses, sugar and tuber crops. Springer, Berlin, Heidelberg, (2007): 175-203.

3. Murad Aline Melro., et al. "Physiological and proteomic analyses of Saccharum spp. grown under salt stress". PLoS One 9.6 (2014): e98463.

4. FAOSTAT (2004).

5. Cheavegatti-Gianotto Adriana., et al. "Sugarcane (Saccharum $\mathrm{X}$ officinarum): a reference study for the regulation of genetically modified cultivars in Brazil". Tropical Plant Biology 4.1 (2011): 62-89.

6. Rott Philippe., et al. "Recent advances in research on Sugarcane yellow leaf virus, the causal agent of sugarcane yellow leaf". Proceedings International Society Sugar Cane Technologists 26 (2007).

7. Lingle Sarah E and Craig L Wiegand. "Soil salinity and sugarcane juice quality”. Field Crops Research 54.2-3 (1997): 259268.
8. Hussain Altaf., et al. "Review Sugarcane, Sugar Metabolism and Some Abiotic Stresses" (2004).

9. Gomathi R and TV Thandapani. "Salt stress in relation to nutrient accumulation and quality of sugarcane genotypes". Sugar Tech 7.1 (2005): 39-47.

10. Cha-um Suriyan., et al. "Screening sugarcane (Saccharum sp.) genotypes for salt tolerance using multivariate cluster analysis". Plant Cell, Tissue and Organ Culture (PCTOC) 110.1 (2012): 23-33.

11. Meinzer Frederick C., et al. "Carbon isotope discrimination, gas exchange, and growth of sugarcane cultivars under salinity". Plant Physiology 104.2 (1994): 521-526.

12. Plaut Zvi., et al. "Leaf development, transpiration and ion uptake and distribution in sugarcane cultivars grown under salinity". Plant and Soil 218.1-2 (2000): 59-69.

13. Wahid Abdul and Alia Ghazanfar. "Possible involvement of some secondary metabolites in salt tolerance of sugarcane". Journal of Plant Physiology 163.7 (2006): 723-730.

14. Errabii Tomader., et al. "Effects of $\mathrm{NaCl}$ and mannitol induced stress on sugarcane (Saccharum sp.) callus cultures". Acta Physiologiae Plantarum 29.2 (2007): 95.

15. Larkin Philip J and Wv R Scowcroft. "Somaclonal variation-a novel source of variability from cell cultures for plant improvement". Theoretical and Applied Genetics 60.4 (1981): 197-214.

16. Samad MA., et al. "Somaclonal variation and irradiation in sugarcane calli for selection against red rot, water-logged conditions and delayed or non-flowering characters. No. IAEA-TECDOC-227 (2001).

17. Bressan RA., et al. "Stable and unstable tolerance to $\mathrm{NaCl}$ in cultured tobacco cells". UCLA symposia on molecular and cellular biology (USA) (1985).

18. González-Rosas H., et al. "Preliminary results on in vitro selection for tolerance to chloride excess in avocado". Revista Chapingo, Texсосо 9.1 (2003): 39-43.

19. Nelson Jr and Oliver E. "The applicability of plant cell and tissue culture techniques to plant improvement". Molecular Genetic Modification of Eucaryotes (1977): 67-76. 
20. Schaeffer GW. "Mutations and cell selections: increased protein from regenerated rice tissue cultures". Environmental and Experimental Botany 21.3-4 (1981): 333-345.

21. Mahmud Kuasha., et al. "Regeneration of sugarcane variety ISD 40 against salt stress condition". Science Technology 2.8 (2016): 485-491.

22. Patade Vikas Yadav., et al. "Halopriming imparts tolerance to salt and PEG induced drought stress in sugarcane". Agriculture, Ecosystems and Environment 134.1-2 (2009): 24-28.

23. Murashige Toshio and Folke Skoog. "A revised medium for rapid growth and bio assays with tobacco tissue cultures". Physiologia Plantarum 15.3 (1962): 473-497.

24. Patade Vikas Yadav., et al. "Salt and drought tolerance of sugarcane under iso-osmotic salt and water stress: growth, osmolytes accumulation, and antioxidant defense". Journal of Plant Interactions 6.4 (2011): 275-282.

25. Patade Vikas Yadav., et al. "Effects of salt stress in relation to osmotic adjustment on sugarcane (Saccharum officinarum L.) callus cultures". Plant Growth Regulation 55.3 (2008): 169.

26. Burner MD. "Regeneration and phenotypic variability of plants cultured in vitro from mature sugarcane caryopses". The Journal of the American Society of Sugar Cane Technologists 12 (1992): 82-90.

27. Watad Abd-Elrahem A., et al. "Enhanced net $\mathrm{K}+$ uptake capacity of NaCl-adapted cells". Plant Physiology 95.4 (1991): 12651269.

28. Medeiros L., et al. "Effect of exogenous proline in two sugarcane genotypes grown in vitro under salt stress". Acta Biológica Colombiana 20.2 (2015): 57-63.

29. Chen Hui and Jian-Guo Jiang. "Osmotic adjustment and plant adaptation to environmental changes related to drought and salinity". Environmental Reviews 18.NA (2010): 309-319.

30. Munns Rana and Mark Tester. "Mechanisms of salinity tolerance". Annual Review of Plant Biology 59 (2008): 651-681.

31. Mancarella S., et al. "Leaf sodium accumulation facilitates salt stress adaptation and preserves photosystem functionality in salt stressed Ocimum basilicum". Environmental and Experimental Botany 130 (2016): 162-173.
32. Benito Begoña., et al. "The twins $\mathrm{K}+$ and $\mathrm{Na}+$ in plants". Journal of Plant Physiology 171.9 (2014): 723-731.

33. Cavalcante Granja Manuela Maria., et al. "Response To In Vitro Salt Stress In Sugarcane Is Conditioned By Concentration And Condition Of Exposure To Naci". Acta Biológica Colombiana 23.1 (2018): 30-38.

\section{Assets from publication with us}

- Prompt Acknowledgement after receiving the article

- Thorough Double blinded peer review

- Rapid Publication

- Issue of Publication Certificate

- High visibility of your Published work

Website: www.actascientific.com/

Submit Article: www.actascientific.com/submission.php Email us: editor@actascientific.com

Contact us: +919182824667 